\title{
Chryseobacterium taichungense sp. nov., isolated from contaminated soil
}

\author{
Correspondence \\ Peter Kämpfer \\ peter.kaempfer@agrar. \\ uni-giessen.de
}

\author{
Fo-Ting Shen, ${ }^{1}$ Peter Kämpfer, ${ }^{2}$ Chiu-Chung Young, ${ }^{1}$ Wei-An Lai ${ }^{1}$ \\ and A. B. Arun ${ }^{1}$ \\ ${ }^{1}$ College of Agriculture and Natural Resources, Department of Soil and Environmental \\ Sciences, National Chung Hsing University, Taichung 402, Taiwan, Republic of China \\ ${ }^{2}$ Institut für Angewandte Mikrobiologie, Justus-Liebig Universität Giessen, Heinrich-Buff-Ring \\ 26-32 (IFZ), D-35392 Giessen, Germany
}

At present, the genus Chryseobacterium contains 12 species: Chryseobacterium balustinum, Chryseobacterium gleum, Chryseobacterium indologenes, Chryseobacterium indoltheticum, Chryseobacterium meningosepticum, Chryseobacterium miricola, Chryseobacterium 'proteolyticum' (name not validated), Chryseobacterium scophthalmum, Chryseobacterium joostei, Chryseobacterium defluvii, Chryseobacterium daecheongense and Chryseobacterium formosense. These species and their taxonomy have been extensively described in recently published reports (Hugo et al., 2003; Li et al., 2003; Kämpfer et al., 2003; Young et al., 2005).

A yellow-pigmented isolate from a tar-contaminated soil from Taichung, Taiwan, was obtained on nutrient agar. This strain (CC-TWGS1-8 $8^{\mathrm{T}}$ ) was maintained and subcultured on nutrient agar (Oxoid) at $30^{\circ} \mathrm{C}$ for $48 \mathrm{~h}$ and subsequently analysed to determine the $16 \mathrm{~S}$ rRNA gene sequence, the fatty acid methyl ester composition of whole-cell hydrolysates, additional phenotypic characteristics, and DNADNA relatedness to those species most closely related on the basis of $16 \mathrm{~S}$ rRNA similarity.

Cultural and morphological characteristics were observed on nutrient agar. The Gram reaction was tested by using the modified method of Gerhardt et al. (1994), while motility

Published online ahead of print on 14 January 2005 as DOI 10.1099/ ijs.0.63514-0.

The GenBank/EMBL/DDBJ accession number for the $16 \mathrm{~S}$ rRNA gene sequence of strain CC-TWGS1-8 ${ }^{\top}$ is AJ843132. was examined microscopically from cells grown for 3 days in motility broth (Cowan, 1974) at $30^{\circ} \mathrm{C}$.

Strain CC-TWGS1-8 ${ }^{\mathrm{T}}$ was Gram-negative and formed visible (about $2 \mathrm{~mm}$ ) yellowish colonies in $48 \mathrm{~h}$ at $30^{\circ} \mathrm{C}$. No growth was observed below $10^{\circ} \mathrm{C}$ or above $37^{\circ} \mathrm{C}$. At $15-36^{\circ} \mathrm{C}$, clearly visible colonies appeared within $48 \mathrm{~h}$. The colonies were translucent and shiny with entire edges, but upon prolonged incubation the colonies were not visible as single entities, probably because of the profuse production of extracellular substances. A bright-yellow pigment (flexirubin) was produced on nutrient agar. Oxidase activity was tested using oxidase reagent (bioMérieux) according to the instructions of the manufacturer. Strain CC-TWGS1-8 ${ }^{\mathrm{T}}$ was oxidase-positive. Cells were non-motile, non-sporeforming rods $\left(1 \mu \mathrm{m}\right.$ wide by $2 \mu \mathrm{m}$ long). CC-TWGS $1-8^{\mathrm{T}}$ was able to grow well on nutrient agar, brain heart infusion agar (Oxoid) and trypticase soy agar (Oxoid) but was unable to grow on MacConkey agar (Oxoid).

Physiological characterization and additional biochemical tests were performed to assess the carbon-source utilization pattern, while the hydrolysis of 19 substrates was investigated as described by Kämpfer et al. (1991). Additional biochemical tests were performed using the Micronaut-E system (formerly called the Titertek-Enterobac-Automated System; Kämpfer, 1990). Growth was also investigated at different temperatures $\left(4,11,30,37\right.$ and $\left.45^{\circ} \mathrm{C}\right)$ in nutrient broth. The API ZYM system (bioMérieux) was used to test for the presence of 19 constitutive enzymes. 
The cellular fatty acid composition (determined using the method described by Kämpfer \& Kroppenstedt, 1996) showed that 15:0 iso was the most abundant fatty acid $(35 \cdot 4 \%)$, followed by $17: 0$ iso $3 \mathrm{OH}(22.5 \%)$ and summed feature $4(15: 0$ iso $2 \mathrm{OH} / 16: 1 \omega 7 t, 13 \cdot 8 \%)$. Table 1 shows the fatty acid pattern for strain CC-TWGS1-8 ${ }^{\mathrm{T}}$ in comparison with those of all other Chryseobacterium species.

The 16S rRNA gene was analysed as described by Kämpfer et al. (2003). A phylogenetic analysis (Fig. 1) was performed using the software package MEGA (Molecular Evolutionary Genetics Analysis) version 2.1 (Kumar et al., 2001) after multiple sequence alignment of data by using CLUSTAL_X (Thompson et al., 1997). Distances (using distance options according to the Kimura two-parameter model) and clustering using the neighbour-joining method and maximum parsimony (all according to Kumar et al., 2001) were determined by using bootstrap values based on 1000 replications. Strain CC-TWGS1-8 ${ }^{\mathrm{T}}$ was phylogenetically most closely related to species of the genus Chryseobacterium. According to the sequence similarity calculations, the most closely related strains were the type strains of $C$. indologenes and C. gleum, both of which showed $96 \cdot 8 \%$ similarity to strain CC-TWGS1-8 ${ }^{\mathrm{T}}$. Furthermore, the type strain of C. joostei showed $96 \cdot 4 \% 16 \mathrm{~S}$ rRNA sequence similarity to CC-TWGS1- ${ }^{\mathrm{T}}$, whereas sequence similarities were below 96.0 \% for all other Chryseobacterium species.
DNA-DNA hybridization experiments were performed with CC-TWGS1- $8^{\mathrm{T}}$ and type strains of the three most closely related Chryseobacterium species, using a method described by Ziemke et al. (1998) (except that for nick translation, $2 \mu \mathrm{g}$ DNA was labelled during a $3 \mathrm{~h}$ incubation at $15^{\circ} \mathrm{C}$ ). Strain CC-TWGS1-8 ${ }^{\mathrm{T}}$ showed relatively low DNA-DNA hybridization to the type strains of $C$. indologenes (LMG $8337^{\mathrm{T}} ; 34 \cdot 1 \%$, reciprocal $25 \cdot 1 \%$ ), C. gleum (LMG $8334^{\mathrm{T}} ; 43 \cdot 4 \%$, reciprocal $35 \cdot 1 \%$ ) and C. joostei (CIP $105533^{\mathrm{T}} ; 10 \cdot 7 \%$, reciprocal $21 \cdot 1 \%$ ).

Strain CC-TWGS1-8 ${ }^{\mathrm{T}}$ utilized only a few carbon sources but was able to hydrolyse many chromogenic substrates. The results of biochemical/physiological tests are given in Table 2 and in the species description.

On the basis of the results of this polyphasic study, it is clear that strain CC-TWGS1-8 ${ }^{\mathrm{T}}$ represents a novel species of the genus Chryseobacterium, for which the name Chryseobacterium taichungense sp. nov. is proposed.

\section{Description of Chryseobacterium taichungense sp. nov.}

Chryseobacterium taichungense (tai.chung' en.se. N.L. neut. adj. taichungense pertaining to Taichung, a province in Taiwan).

Table 1. Long-chain fatty acid composition of Chryseobacterium species and related bacteria

Taxa: 1, C. taichungense sp. nov. $(n=1) ; 2$, C. formosense $(n=1) ; 3$, C. defluvii $(n=1) ; 4$, C. joostei $(n=11) ; 5, C$. gleum $(n=5)$; 6, C. indologenes $(n=45) ; 7$, C. balustinum $(n=1) ; 8$, C. indoltheticum $(n=1) ; 9$, C. scophthalmum $(n=2) ; 10$, C. meningosepticum ( $n=1)$; 11, C. miricola $(n=1) ; 12$, Bergeyella zoohelcum $(n=1) ; 13$, Empedobacter brevis $(n=6)$. Fatty acid percentages amounting to less than $1 \%$ of the total fatty acids in all strains were not included. Means \pm SD are given. Tr, Trace (less than $1.0 \%$ ); ND, not detected. Data are from Hugo et al. (2003), Kämpfer et al. (2003), Li et al. (2003) and Young et al. (2005).

\begin{tabular}{|c|c|c|c|c|c|c|c|c|c|c|c|c|c|}
\hline Fatty acid & 1 & 2 & 3 & 4 & 5 & 6 & 7 & 8 & 9 & 10 & 11 & 12 & 13 \\
\hline Unknown $13 \cdot 566^{\star}$ & $6 \cdot 7$ & $\operatorname{Tr}$ & $\operatorname{Tr}$ & $1 \cdot 1 \pm 0 \cdot 2$ & $1 \cdot 2 \pm 0 \cdot 4$ & $2 \cdot 1 \pm 0 \cdot 7$ & $1 \cdot 6$ & $1 \cdot 7$ & $2 \cdot 9 \pm 0 \cdot 2$ & $1 \cdot 5$ & $\operatorname{Tr}$ & $1 \cdot 8$ & $1 \cdot 9 \pm 1 \cdot 4$ \\
\hline $15: 0$ iso $3 \mathrm{OH}$ & $4 \cdot 3$ & $1 \cdot 8$ & $2 \cdot 6$ & $2 \cdot 9 \pm 0 \cdot 3$ & $2 \cdot 5 \pm 0 \cdot 1$ & $2 \cdot 6 \pm 0 \cdot 2$ & $2 \cdot 7$ & $2 \cdot 3$ & $2 \cdot 7 \pm 0 \cdot 1$ & $3 \cdot 5$ & 3 & $3 \cdot 95$ & $4 \cdot 8 \pm 0 \cdot 7$ \\
\hline $15: 0$ anteiso & $0 \cdot 7$ & $2 \cdot 1$ & $3 \cdot 2$ & $\operatorname{Tr}$ & $\operatorname{Tr}$ & $\operatorname{Tr}$ & $\operatorname{Tr}$ & $5 \cdot 9$ & $\operatorname{Tr}$ & $2 \cdot 3$ & $\operatorname{Tr}$ & ND & $\operatorname{Tr}$ \\
\hline $16: 0$ & $1 \cdot 3$ & $1 \cdot 5$ & $1 \cdot 3$ & $\operatorname{Tr}$ & $1 \cdot 3 \pm 0 \cdot 4$ & $\operatorname{Tr}$ & $1 \cdot 6$ & $1 \cdot 0$ & $1 \cdot 2 \pm 0 \cdot 2$ & $\operatorname{Tr}$ & 2 & $\operatorname{Tr}$ & $3 \cdot 8 \pm 0 \cdot 4$ \\
\hline $16: 0$ iso $3 \mathrm{OH}$ & $1 \cdot 4$ & $1 \cdot 1$ & $\operatorname{Tr}$ & ND & ND & $\mathrm{ND}$ & $\operatorname{Tr}$ & $1 \cdot 3$ & $\mathrm{ND}$ & $\operatorname{Tr}$ & $\operatorname{Tr}$ & ND & $\operatorname{Tr}$ \\
\hline Unknown $16 \cdot 580^{*}$ & $1 \cdot 7$ & $1 \cdot 0$ & $\mathrm{ND}$ & $1 \cdot 6 \pm 0 \cdot 1$ & $1 \cdot 7 \pm 0 \cdot 1$ & $1 \cdot 7 \pm 0 \cdot 2$ & $1 \cdot 3$ & $1 \cdot 3$ & $1 \cdot 5 \pm 0 \cdot 1$ & $1 \cdot 7$ & $\operatorname{Tr}$ & $1 \cdot 4$ & $1 \cdot 4 \pm 0 \cdot 1$ \\
\hline $17: 02 \mathrm{OH}$ & ND & ND & $\mathrm{ND}$ & ND & ND & ND & $\operatorname{Tr}$ & $3 \cdot 0$ & $\operatorname{Tr}$ & $\operatorname{Tr}$ & $\mathrm{ND}$ & ND & $\operatorname{Tr}$ \\
\hline $17: 0$ iso & $0 \cdot 8$ & $2 \cdot 3$ & $2 \cdot 0$ & $\operatorname{Tr}$ & $1 \cdot 6 \pm 0 \cdot 6$ & $\operatorname{Tr}$ & $1 \cdot 0$ & $\operatorname{Tr}$ & $\operatorname{Tr}$ & $\operatorname{Tr}$ & 1 & $\mathrm{ND}$ & $\operatorname{Tr}$ \\
\hline $17: 0$ iso $3 \mathrm{OH}$ & $22 \cdot 4$ & $10 \cdot 9$ & $14 \cdot 1$ & $20 \cdot 1 \pm 1 \cdot 2$ & $21 \cdot 8 \pm 0 \cdot 3$ & $19 \cdot 2 \pm 1 \cdot 8$ & $16 \cdot 8$ & $14 \cdot 0$ & $16 \cdot 3 \pm 0 \cdot 1$ & $16 \cdot 3$ & 40 & $13 \cdot 5$ & $17 \cdot 1 \pm 2 \cdot 1$ \\
\hline
\end{tabular}

${ }^{*}$ Unknown fatty acid; numbers indicate equivalent chain length.

$\dagger$ Fatty acids that could not be separated by GC using the Microbial Identification System (Microbial ID) software were considered summed features. Summed feature 4 contains $15: 0$ iso $2 \mathrm{OH}$ and/or $16: 1 \omega 7$ t. Summed feature 5 contains $17: 1$ iso I and/or $17: 1$ anteiso B. 


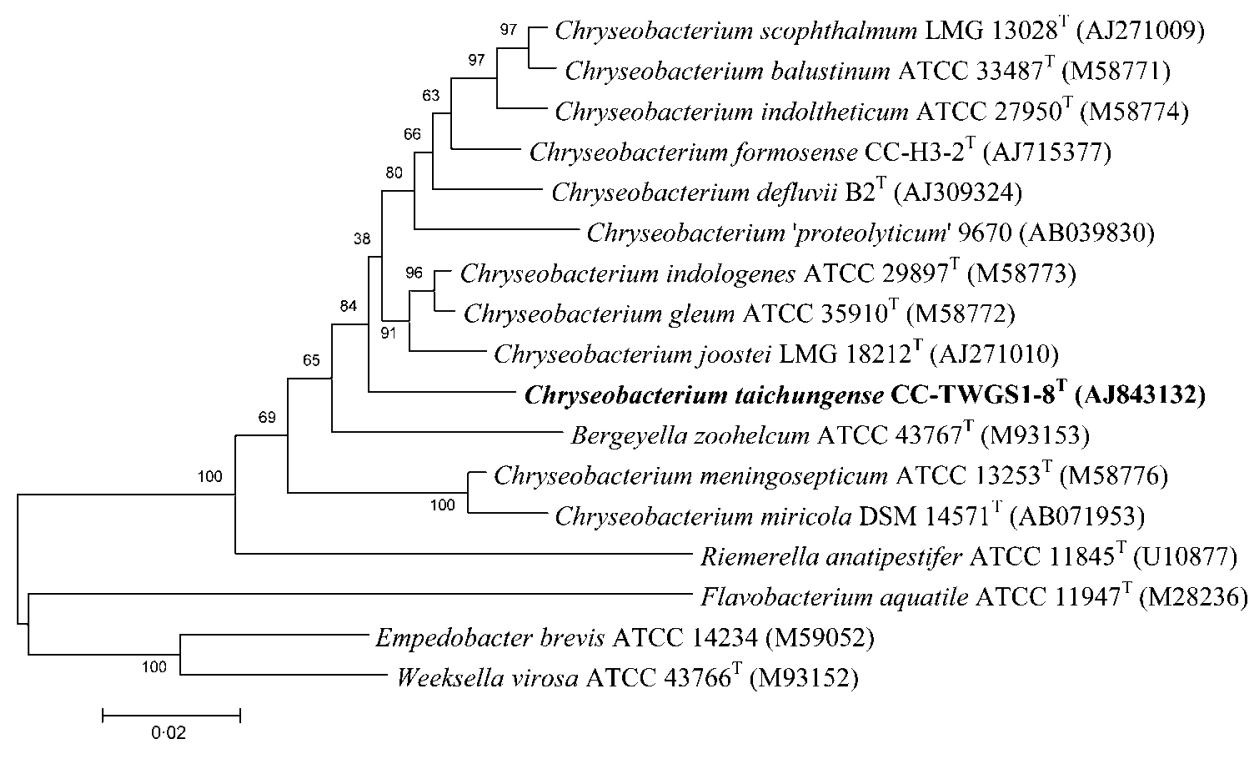

Fig. 1. Phylogenetic analysis based on 16S rRNA gene sequences available from the European Molecular Biology Laboratory database (accession numbers are given in parentheses), constructed after multiple alignment of data by using CLUSTAL_X (Thompson et al., 1997). Distances (distance options according to the Kimura two-parameter model) and clustering with the neighbour-joining method were determined by using the software packages MEGA (Molecular Evolutionary Genetics Analysis) version 2.1 (Kumar et al., 2001). Bootstrap values, based on 1000 replications, are given as percentages at the branching points. Bar, $0.02 \mathrm{nt}$ substitution $\left(K_{\text {nuc }}\right)$ unit.

Table 2. Comparison of characteristics of strain CC-TWGS1-8 ${ }^{\top}$ with those of other reported Chryseobacterium species

Species: 1, C. taichungense; 2, C. formosense, 3, C. defluvii; 3, 4, C. 'proteolyticum' $(n=2)$; 5, C. gleum $(n=12)$; 6, C. indologenes $(n=13)$; 7, C. balustinum $(n=1) ; 8$, C. indoltheticum $(n=1) ; 9$, C. meningosepticum $(n=49) ; 10$, C. scophthalmum $(n=7)$; 11, C. joostei $(n=11)$; 12, C. miricola $(n=1)$. Data for reference species were taken from Kämpfer et al. (2003), Li et al. (2003), Hugo et al. (2003) and Young et al. (2005). $n$, Number of strains tested; +, all strains tested positive; $(+)$, weakly positive; -, all strains tested negative; NA, not available. Two figures separated by a solidus (/) refer to the number of positive strains out of the number of strains tested.

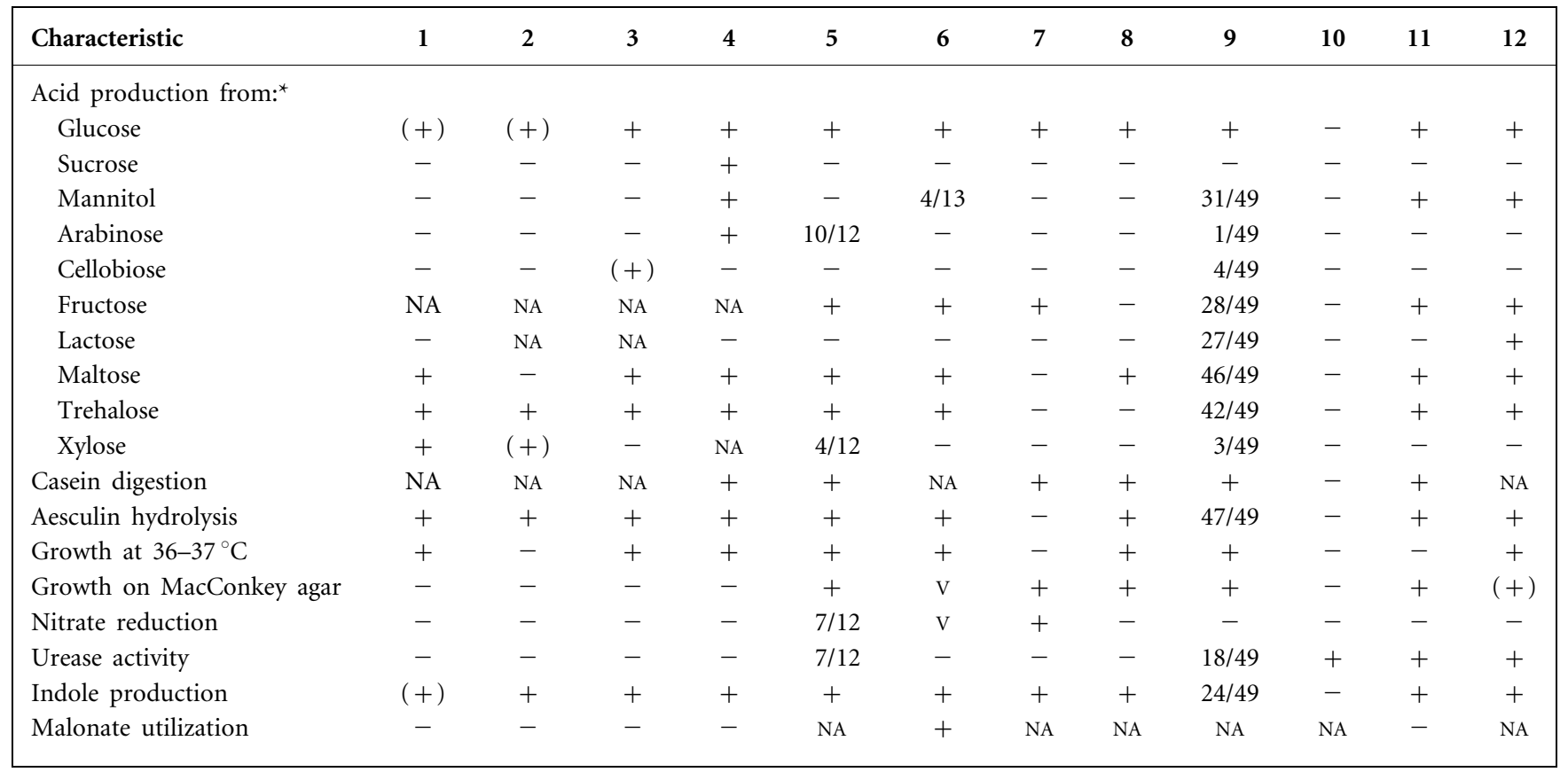

${ }^{\star}$ Different methods were used for testing acid formation from different sugars; the original reports should be consulted for direct comparisons. 
Cells are Gram-negative, non-motile, non-spore-forming rods (approx. $2 \mu \mathrm{m}$ in length). Aerobic, oxidase-positive, shows good growth after $48 \mathrm{~h}$ on nutrient agar, brain heart infusion agar and trypticase soy agar at $11-36{ }^{\circ} \mathrm{C}$, but unable to grow on MacConkey agar. Colonies on nutrient agar are smooth, yellowish, circular, translucent and shiny with entire edges, becoming mucoid and unidentifiable as single entities after prolonged incubation. The yellow pigmentation is non-diffusible and non-fluorescent. Unable to grow at 4 and $45^{\circ} \mathrm{C}$. Positive for gelatinase activity. Grows well over a broad range of $\mathrm{pH}$ values $(6 \cdot 0-9 \cdot 0)$ but grows better in neutral or weakly alkaline conditions $(\mathrm{pH} \mathrm{7 \cdot 0-}$ $8 \cdot 0$ ). Major cellular fatty acids are 15:0 iso and 17:0 iso $3 \mathrm{OH}$. Positive reactions observed for alkaline phosphatase, butyrate esterase, carprylate esterase, myristate lipase, leucine arylamidase, valine arylamidase, cystine arylamidase, trypsin, $\alpha$-chymotrypsin, acid phosphatase, naphtholAS-Bl-phosphohydrolase, $\beta$-glucuronidase, $\alpha$-glucosidase, $\beta$-glucosidase and $N$-acetyl- $\beta$-glucosaminidase. No enzymic activities found for $\alpha$-galactosidase, $\alpha$-mannosidase or $\alpha$ fucosidase. Weakly positive for indole production, cytochrome oxidase activity and $\beta$-galactosidase (ONPG test), but negative for arginine dihydrolase, lysine decarboxylase, citrate utilization, $\mathrm{H}_{2} \mathrm{~S}$ production, urease and tryptophan deaminase. Strain CC-TWGS1-8 ${ }^{\mathrm{T}}$ shows weak production of acid from adonitol, D-glucose, i-inositol, D-maltose, Lrhamnose, D-trehalose and D-xylose. No acid is produced from L-arabinose, D-arabitol, dulcitol, erythritol, lactose, D-mannitol, D-melibiose, methyl $\alpha$-D-glucoside, raffinose, salicin, D-sorbitol or sucrose. The following compounds are not utilized as sole sources of carbon: D-glucose, D-maltose, D-mannose, D-trehalose, acetate, propionate, $N$-acetylgalactosamine, $\mathrm{N}$-acetylglucosamine, L-arabinose, L-arbutin, D-cellobiose, D-galactose, gluconate, glycerol, D-fructose, D-mannitol, maltitol, $\alpha$-D-melibiose, L-rhamnose, D-ribose, D-sucrose, salicin, D-trehalose, D-xylose, adonitol, i-inositol, D-sorbitol, putrescine, cis-aconitate, trans-aconitate, 4aminobutyrate, adipate, azelate, fumarate, glutarate, DL-3hydroxybutyrate, itaconate, DL-lactate, 2-oxoglutarate, pyruvate, suberate, citrate, mesaconate, L-alanine, $\beta$ alanine, L-ornithine, L-phenylalanine, L-serine, L-aspartate, L-histidine, L-leucine, L-proline, L-tryptophan, 3-hydroxybenzoate, 4 -hydroxybenzoate and phenylacetate. The chromogenic substrates $p$-nitrophenyl- $\alpha$-D-glucopyranoside, $p$-nitrophenyl- $\beta$-D-glucopyranoside, $\quad p$-nitrophenyl- $\beta$-Dgalactopyranoside and $p$-nitrophenyl- $\beta$-D-xylopyranoside, bis( $p$-nitrophenyl) phosphate, bis( $p$-nitrophenyl) phenylphosphonate, bis- $p$-nitrophenylphosphorylcholine, 2 -deoxythymidine $2^{\prime}$-p-nitrophenyl-phosphate, L-alanine$p$-nitroanilide, $\quad \gamma$-L-glutamate- $p$-nitroanilide and $\mathrm{L}$ proline- $p$-nitroanilide are hydrolysed. $p$-Nitrophenyl $\beta$-D-glucuronide is not hydrolysed.
The type strain is CC-TWGS1-8 ${ }^{\mathrm{T}}\left(=\right.$ CCUG $50001^{\mathrm{T}}=$ CIP $108519^{\mathrm{T}}$ ), which was isolated from tar-contaminated soil in Taichung, Taiwan.

\section{Acknowledgements}

This research work was kindly supported by a grant from the National Science Council and the Council of Agriculture, Executive Yuan, Taiwan, Republic of China.

\section{References}

Cowan, S. T. (1974). Cowan and Steel's Manual for the Identification of Medical Bacteria, 2nd edn. Cambridge: Cambridge University Press.

Gerhardt, P., Murray, R. G. E., Wood, W. A. \& Krieg, N. R. (editors) (1994). Methods for General and Molecular Bacteriology. Washington, DC: American Society for Microbiology.

Hugo, C. J., Segers, P., Hoste, B., Vancanneyt, M. \& Kersters, K. (2003). Chryseobacterium joostei sp. nov., isolated from the dairy environment. Int J Syst Evol Microbiol 53, 771-777.

Kämpfer, P. (1990). Evaluation of the Titertek-Enterobac-Automated System (TTE-AS) for identification of members of the family Enterobacteriaceae. Zentralbl Bakteriol 273, 164-172.

Kämpfer, P. \& Kroppenstedt, R. M. (1996). Numerical analysis of fatty acid patterns of coryneform bacteria and related taxa. Can J Microbiol 42, 989-1005.

Kämpfer, P., Steiof, M. \& Dott, W. (1991). Microbiological characterisation of a fuel-oil contaminated site including numerical identification of heterotrophic water and soil bacteria. Microb Ecol 21, 227-251.

Kämpfer, P., Dreyer, U., Neef, A., Dott, W. \& Busse, H.-J. (2003). Chryseobacterium defluvii sp. nov., isolated from wastewater. Int J Syst Evol Microbiol 53, 93-97.

Kumar, S., Tamura, K., Jakobsen, I. B. \& Nei, M. (2001). MEGA2: Molecular Evolutionary Genetics Analysis software. Bioinformatics 17, 1244-1245.

Li, Y., Kawamura, Y., Fujiwara, N., Naka, T., Liu, H., Huang, X., Kobayashi, K. \& Ezaki, T. (2003). Chryseobacterium miricola sp. nov., a novel species isolated from condensation water of space station Mir. Syst Appl Microbiol 26, 523-528.

Thompson, J. D., Gibson, T. J., Plewniak, F., Jeanmougin, F. \& Higgins, D. G. (1997). The CLUSTAL_X Windows interface: flexible strategies for multiple sequence alignment aided by quality analysis tools. Nucleic Acids Res 25, 4876-4882.

Young, C.-C., Kämpfer, P., Shen, F.-T., Lai, W.-A. \& Arun, A. B. (2005). Chryseobacterium formosense sp. nov., isolated from the rhizosphere of Lactuca sativa L. (garden lettuce). Int J Syst Evol Microbiol 55, 423-426.

Ziemke, F., Höfle, M. G., Lalucat, J. \& Rosselló-Mora, R. (1998). Reclassification of Shewanella putrefaciens Owen's genomic group II as Shewanella baltica sp. nov. Int J Syst Bacteriol 48, 179-186. 